\title{
Achieving superplasticity in a Bi-Sn alloy processed by high- pressure torsion
}

\author{
C. T. Wang ${ }^{1 \dagger}$, T. G. Langdon ${ }^{2,3}$ \\ ${ }^{\dagger}$ ctwang@njust.edu.cn

\begin{abstract}
${ }^{1}$ School of Mechanical Engineering, Nanjing University of Science \& Technology, Nanjing 210094, China Los Angeles, CA 90089-1453, U.S. A.

${ }^{3}$ Materials Research Group, Faculty of Engineering and the Environment, University of Southampton, Southampton SO171BJ, U. K.
\end{abstract} \\ ${ }^{2}$ Departments of Aerospace \& Mechanical Engineering and Materials Science, University of Southern California,
}

\begin{abstract}
A Bi-Sn alloy was processed by high-pressure torsion (HPT) at room temperature for 10 turns to achieve a homogeneous fine microstructure. Microhardness observations showed that the refined microstructure experienced self-annealing during storage at room temperature. The microhardness of HPT processed samples was increased after storage at room temperature but the grain size of the samples was increased. Following HPT processing and storage at room temperature for 35 days, a sample had excellent superplastic properties when testing at room temperature. The HPT processed sample had an elongation to failure of $>1200 \%$ when testing at an initial tensile strain rate of $1.0 \times 10^{-4} \mathrm{~s}^{-1}$, while a coarse-grained sample only exhibited an elongation to failure of $110 \%$ at the same testing condition. An HPT-processed tensile sample was polished carefully and pulled at an initial tensile strain rate of $1.0 \times 10^{-4} \mathrm{~s}^{-1}$ to a strain of 0.3 , and observations of the microstructure showed that Bi-Sn and $\mathrm{Sn}$-Sn boundaries had excellent grain boundary sliding behavior whereas cavities were formed on Bi-Bi boundaries. The enhanced superplastic flow behavior of the fine-grained Bi-Sn alloy was attributed to the homogeneously distributed Bi-Sn and $\mathrm{Sn}$-Sn boundaries after HPT processing since these are preferred sites for grain boundary sliding.
\end{abstract}

Keywords: Bi-Sn alloy, grain boundary sliding, high-pressure torsion, severe plastic deformation, superplasticity

\section{Достижение сверхпластичности в сплаве Bi-Sn, деформированном кручением под высоким давлением}

Сплав Bi-Sn был продеформирован кручением под высоким давлением (КВД) при комнатной температуре до 10 оборотов с целью достижения однородной мелкозернистой структуры. Измерения микротвердости показали, что измельченная микроструктура испытывает самоотжиг при выдержке при комнатной температуре. Микротвердость образцов повысилась после выдержки при комнатной температуре, но размер зерен образцов увеличилась. После деформации КВД и выдержки при комнатной температуре в течение 35 дней образец имел отличные сверхпластические свойства при испытаниях при комнатной температуре. Образец после КВД проявил удлинение до разрушения более $1200 \%$ при испытаниях с начальной скоростью деформации $1.0 \times 10^{-4} \mathrm{c}^{-1}$, тогда как крупнозернистый образец показал удлинение до разрушения только $110 \%$ при тех же условиях испытаний. Подвергнутый КВД образец для растяжения был тщательно отполирован и испытан при скорости деформации растяжением $1.0 \times 10^{-4} \mathrm{c}^{-1}$ до степени деформации 0.3, и наблюдения микроструктуры показали, что границы Bi-Sn и Sn-Sn испытывают отличное зернограничное проскальзывание, тогда как в границах Вi-Bi образуются поры. Повышенные сверхпластические свойства мелкозернистого сплава Bi-Sn объяснены однородным распределением границ Bi-Sn и Sn-Sn после деформации КВД, так как они являются предпочтительными участками зернограничного проскальзывания.

Ключевые слова: сплав Bi-Sn, зернограничное проскальзывание, кручение под высоким давлением, интенсивная пластическая деформация, сверхпластичность

\section{Introduction}

Superplastic deformation refers to the ability of some metallic alloys to pull out to large tensile elongations, normally larger than $400 \%$, before final failure [1]. Metallic alloys may deform at elevated temperatures by various creep processes including dislocation climb where $n \approx 5$, dislocation glide where $\mathrm{n}=3$ and superplastic flow where $\mathrm{n}=2$, where $n$ is the 
stress exponent corresponding to the reciprocal of the strain rate sensitivity [2]. It is now well recognized that two conditions are required for superplastic flow [3]. First, the testing must be conducted at a relatively high temperature, typically $\geq 0.5 T_{m}$, where $T_{m}$ is the absolute melting temperature of the metal. Second, the tested material should have a small and stable grain size so that grain boundary sliding can occur easily. It is rather difficult to fulfill both of these requirements for most materials as grain growth will occur at elevated temperatures, especially in pure metals and simple solid solution alloys. Therefore, optimal superplastic metals tend to be two-phase alloys where grain growth is limited by the presence of two phases. The first study achieving true superplastic deformation in metals was performed on a $\mathrm{Bi}$ Sn eutectic alloy [4]. In this study, the Bi-Sn eutectic alloy was extruded and aged for 7 days and the sample was pulled under a constant stress of $\sim 1.7 \mathrm{MPa}$ until an impressive elongation to failure of $\sim 1950 \%$. More recently, a remarkable elongation of $7550 \%$ was reported in a $\mathrm{Pb}-62 \% \mathrm{Sn}$ eutectic alloy [5].

Much attention has focused recently on processing ultrafine grained (UFG) metals via severe plastic deformation (SPD) in order to achieve exceptional grain refinement [6]. There are now several different SPD processing methods, but most attention is generally directed to equal-channel angular pressing (ECAP) [7] and high-pressure torsion (HPT) [8]. These UFG materials produced by SPD methods generally exhibit high strength at ambient temperatures and, if the grain size remains small at elevated temperatures, it is also possible to achieve excellent superplastic properties in these UFG materials.

The present investigation was initiated to study the effect of HPT processing on superplasticity in the Bi-Sn alloy. Thus, the present tests were undertaken with two steps. Firstly, to investigate the grain refinement and mechanical property evolution after HPT processing. Secondly, to determine the optimum testing conditions in order to achieve superplastic ductilities during tensile testing.

\section{Experimental material and procedures}

The $\mathrm{Bi}-42 \% \mathrm{Sn}$ eutectic alloy was supplied as a cast ingot with approximate dimensions of $55 \times 35 \times 250 \mathrm{~mm}^{3}$. Thin disksamples with diameters of $10 \mathrm{~mm}$ were machined from the cast ingot and these disks were then carefully ground to give disk thicknesses between 0.80 and $0.85 \mathrm{~mm}$.

The HPT processing was conducted under quasi-constrained conditions where there was some restricted outflow of material around the periphery of the sample during the processing operation $[9,10]$. The HPT facility consisted of massive upper and lower anvils that were arranged in a vertical alignment. Each anvil had a circular depression on the inner face with a diameter of $10 \mathrm{~mm}$ and a depth of 0.25 $\mathrm{mm}$. For HPT processing, a disk was placed in the depression on the lower anvil, the lower anvil was then raised to hold the disk between the two anvils, a pressure of $6.0 \mathrm{GPa}$ was imposed on the disk and then torsional straining was generated by rotation of the lower anvil. Various total strains were imposed on the disks by processing for 10 revolutions at a constant rotation speed of $1 \mathrm{rpm}$.

After HPT processing, disks of both the as-cast and the HPT-processed Bi-Sn alloy were polished by abrasive papers to 1600 grit followed by polishing to $1 \mu \mathrm{m}$ with diamond suspensions. Finally, vibratory polishing was performed with a $0.04 \mu \mathrm{m}$ colloidal silica suspension to remove any scratches. The microhardness values relate directly to the microstructures in the materials. Microhardness measurements were taken on the polished surfaces using an FM-1e Vickers hardness tester using a load of $50 \mathrm{gf}$ with a dwell time of $10 \mathrm{~s}$ for each individual indentation. Due to the limited size of the HPT disks, two miniature tensile specimens with gauge lengths of $1 \mathrm{~mm}$ were machined from off-center positions in the HPT disks according to the procedure described earlier [11]. A special sample holder was designed to fit the tensile sample within the testing machine. These specimens were tested in tension using an Instron facility at room temperature operating under conditions of constant cross-head displacement with initial strain rates from $1.0 \times 10^{-4}$ to $1.0 \times 10^{-2} \mathrm{~s}^{-1}$.

A solution of $25 \mathrm{ml} \mathrm{H}_{2} \mathrm{O}, 5 \mathrm{ml} \mathrm{HCl}$ with a concentration of $37 \%$ and $5 \mathrm{~g}$ of $\mathrm{NH}_{4} \mathrm{NO}_{3}$ was used as the etchant. The microstructure was observed using a scanning electron microscope (SEM) JEOL JSM-7001 F at an operating voltage of 15 $\mathrm{kV}$. The SEM was equipped with an electron backscatter diffraction (EBSD) detector and used a TSL orientation imaging system and OIM ${ }^{\mathrm{Tm}}$ software to analyze the results. The EBSD data were collected at a working distance of $15 \mathrm{~mm}$ with a sample tilt of $70^{\circ}$.

\section{Experimental results}

Figure 1 shows the microhardness of the Bi-Sn alloy after HPT processing and its evaluation versus number of storage days at room temperature, with the upper dashed line showing the hardness of the as-cast Bi-Sn alloy without HPT processing. The microhardness measurements were taken around $2 \mathrm{~mm}$ away from the centers of the disks. It is clear that the as-cast Bi-Sn alloy has a higher microhardness of about $25.2 \mathrm{Hv}$ which decreased dramatically to about $9 \mathrm{Hv}$ after HPT processing. As the alloy has a very low melting

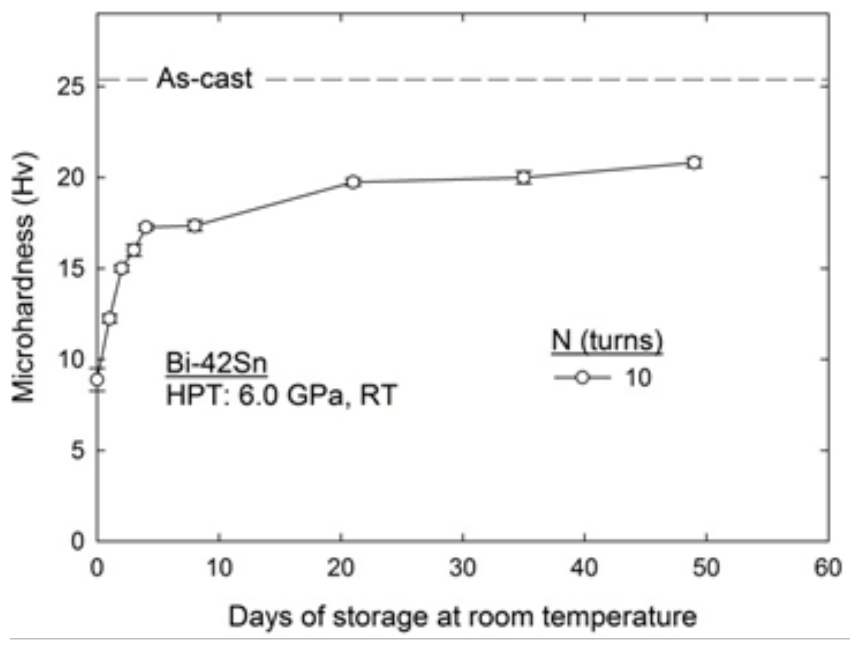

Fig. 1. Microhardness evoluation of HPT processed Bi-Sn alloy versus number of storage days at room temperature. 
temperature of $411 \mathrm{~K}$, the ultrafine microstructure was not stable and experienced self-annealing when held at room temperature $(298 \mathrm{~K})$. The microhardness of the Bi-Sn alloy increased slowly after HPT processing and reached a relatively stable level after about 20 days of storage with a hardness of $\sim 20 \mathrm{Hv}$.

Figure 2 shows the microstructure of the Bi-Sn alloy before and after HPT processing, where this demonstrates evidence of recovery of the ultrafine microstructure at room temperature. These microstructure images were also taken about $2 \mathrm{~mm}$ away from the centers of the disks to maintain

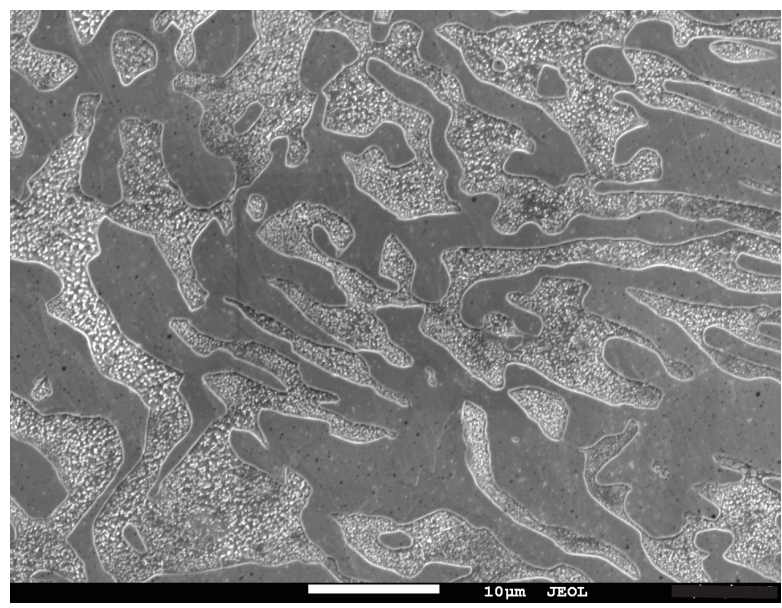

a

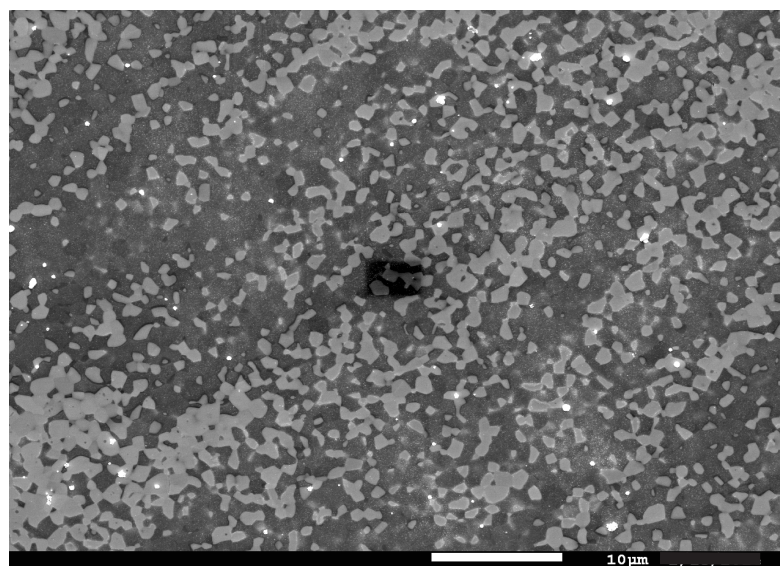

b

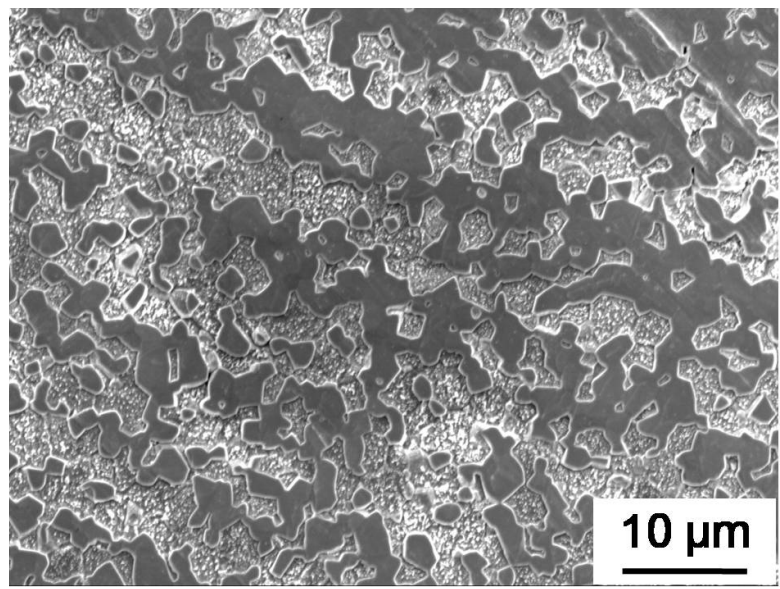

C

Fig. 2. Microstructure of the Bi-Sn alloy: (a) as-cast; (b) HPT processed and stored at room temperature for 1 day; (c) HPT processed and stored at room temperature for 35 days.

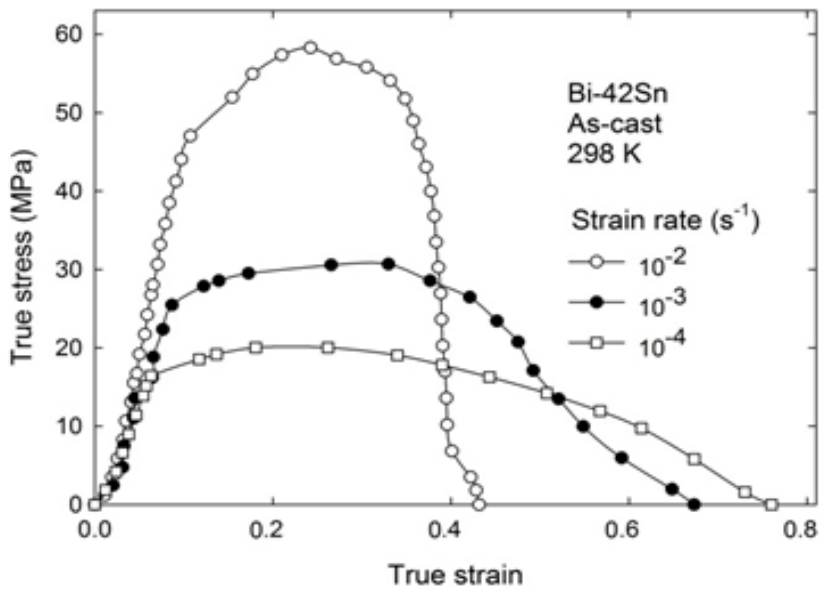

a

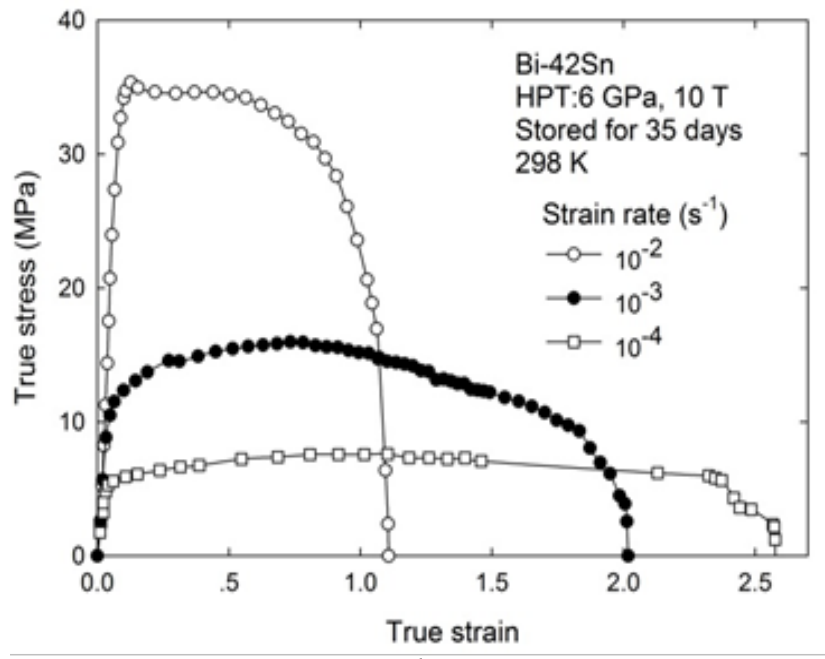

b

Fig. 3 True stress-true strain curves for Bi-Sn alloy under different strain rates at room temperature: (a) as-cast and (b) storage for 35 days after HPT processing for 10 turns.

consistency with the microhardness measurements and the tensile tests. The as-cast alloy has a lamellar structure as shown in Fig. 2a, Fig. 2b shows a very fine and homogeneous structure after HPT processing where the coarse lamellae of $\mathrm{Bi}$ and $\mathrm{Sn}$ are broken down into equiaxed particles and evenly distributed after HPT processing. Fig. 2c shows that the fine particles of $\mathrm{Bi}$ and $\mathrm{Sn}$ are moving and connecting with the same phase during storage at room temperature.

It is believed that the structure shown in Fig. $2 \mathrm{c}$ is relatively stable for the HPT processed samples because the microhardness was stable between totals of 20 and 50 days of storage at room temperature as shown in Fig. 1. Therefore, all HPT processed samples were stored at room temperature for 35 days prior to tensile testing and thus it is reasonable to neglect the effect of any self-annealing of the alloy during the tensile testing. Tensile samples were pulled to failure at a temperature of $298 \mathrm{~K}$ under initial strain rates of $1.0 \times 10^{-2}, 1.0 \times 10^{-3}$ and $1.0 \times 10^{-4} \mathrm{~s}^{-1}$

Fig. 3 shows plots of the true stress versus the true strain for samples of the Bi-Sn alloy during tensile testing under different initial strain rates at room temperature. Both sets of stress-strain curves are similar with a relatively higher yield stress at the higher strain rate and a lower yield stress at 

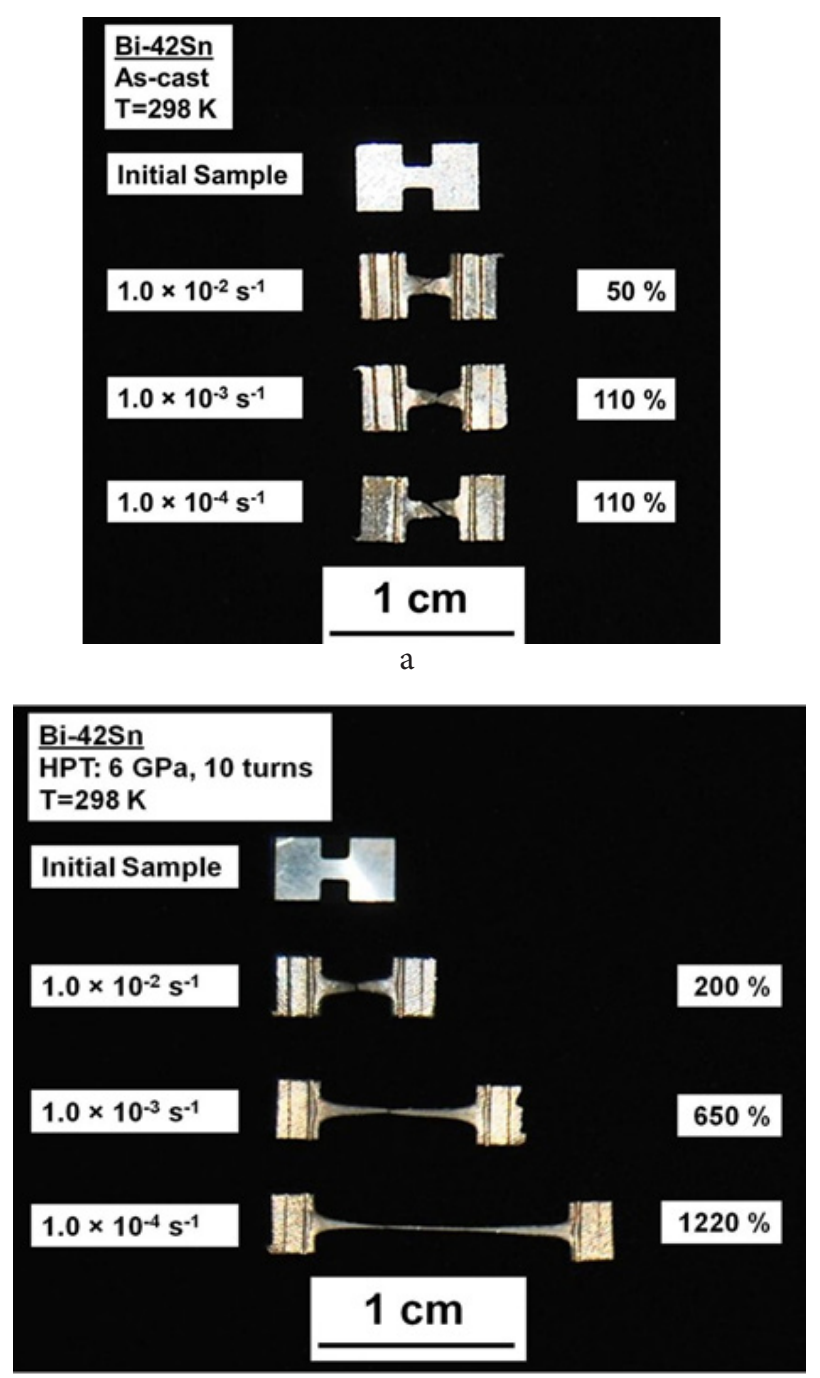

b

Fig. 4 Appearance of specimens of Bi-Sn alloy after testing to failure at room temperature with different initial strain rates: (a) as-cast and (b) storage for 35 days after HPT processing for 10 turns.

the lower strain rate for each sample. Moreover, inspection shows that the as-cast Bi-Sn sample had higher stresses compared to the fine-grained alloy under the same strain rate, where this is constant with the microhardness data shown in Fig. 1.

The appearance of the specimens of the Bi-Sn alloy after testing to failure at room temperature with different initial strain rates is shown in Fig. 4. It is clear that the as-cast material exhibits much lower elongations to failure compared to the fine-grained Bi-Sn alloy processed by HPT. For both samples, the lower strain rate led to a higher tensile elongation but this was only $110 \%$ in the as-cast condition whereas it was $1220 \%$ under a strain rate of $1.0 \times 10^{-4} \mathrm{~s}^{-1}$ for the material processed by HPT through 10 turns. The elongation of $1220 \%$ confirms the occurrence of excellent superplastic behavior in this alloy after HPT processing. Furthermore, close inspection of Fig. 4 shows that the highly superplastic sample pulls out in a very uniform manner with no evidence for the formation of any necking within the gauge length. An absence of necking within the gauge length is an important additional requirement of true superplastic flow [12].

\section{Discussion}

The present results show that HPT processing is effective in producing grain refinement in the Bi-Sn eutectic alloy but the ultrafine structure is not stable at room temperature. A relatively homogeneous and fine mircostructure was achieved after 35 days storage at room temperature after HPT processing.

Tensile tests showed that the grain refinement of HPT processing produced an excellent superplastic behavior in the $\mathrm{Bi}-\mathrm{Sn}$ alloy which is similar to reports in other eutectic and eutectoid alloys [13-15]. A theoretical model for superplasticity was developed recently in which flow occurs by grain boundary sliding which is controlled by the rate of accommodation by intragranular slip in which accommodating dislocations move into the adjacent grains [16]. There is direct experimental evidence for the occurrence of intragranular slip during superplasticity [17] and it has been shown that this theoretical mechanism is in good agreement with experimental evidence in some UFG aluminum and magnesium alloys processed by ECAP $[18,19]$.

Figure 5 shows the microstructure of fine grained Bi-Sn alloy before and after tensile straining of $30 \%$. Fig. $5 \mathrm{a}$ is the

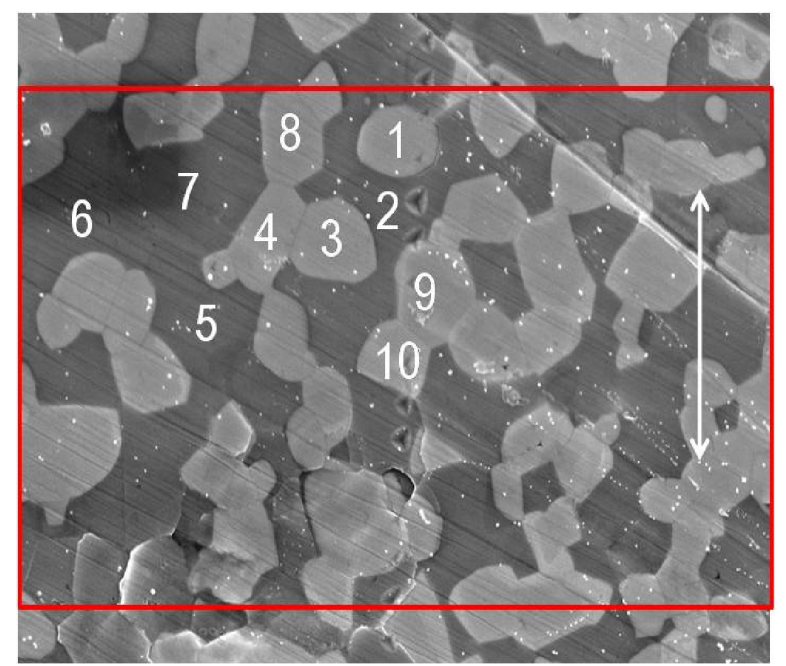

a

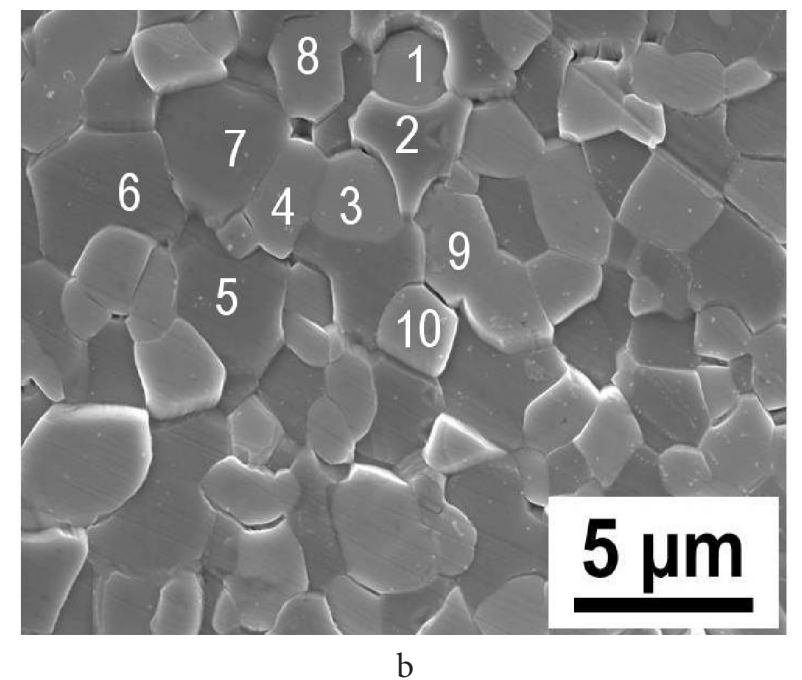

Fig. 5 Microstructure of fine grained Bi-Sn alloy: (a) before and (b) after testing to $30 \%$ strain at room temperature. 
structure of the Bi-Sn alloy processed by HPT for 10 turns and stored at room temperature for 35 days: the white arrow in Fig. 5a denotes the tensile direction and the numbers in both images are used to label the same grains before and after tensile straining. Fig. 5b shows the microstructure of the same sample after tensile straining of $30 \%$ at an initial strain rate of $1.0 \times 10^{-4} \mathrm{~s}^{-1}$. The brighter grains in Fig. 5a are Bi grains while the darker grains are Sn grains. As clearly shown in Fig. 5b, cavities are formed after a tensile strain of $30 \%$, for instance between grains 4 and 8 and also between grains 9 and 10. Moreover, evidence of grain boundary sliding is also shown in Fig. 5b by noting some movement of neighbouring grains along the grain boundaries: for instance, there is sliding between grains 1 and 2 and also between grains 2 and 3 .

\section{Summary and conclusions}

1. Experiments were conducted on a Bi-Sn alloy to investigate the grain refinement and superplastic behavior achieved by HPT processing.

2. The fine grained Bi-Sn alloy exhibits lower flow stresses and significantly higher elongations to failure after processing by HPT. The elongations to failure were in the superplastic regime and exceeded $1200 \%$ at room temperature.

3. Grain boundary sliding was observed on the Bi-Sn and $\mathrm{Sn}$-Sn boundaries while cavities formed on the Bi-Bi boundaries.

Acknowledgements. This work was supported in part by the National Science Foundation of the United States under Grant No. DMR-1160966 and in part by the European Research Council under ERC Grant Agreement No. 267464-SPDMETALS.

\section{References}

1. T.G. Langdon, J. Mater. Sci. 44, 5998 (2009).

2. T.G. Langdon, Metall. Trans. 13A, 689 (1982).

3. T.G. Langdon, Mater. Trans. 46, 1951 (2005).

4. C.E Pearson J. Inst. Metals. 54, 111 (1934).

5. Y. Ma, T.G. Langdon, Metall. Mater. Trans. A 25A, 2309 (1994).

6. T.G. Langdon, Acta Mater. 61, 7035 (2013).

7. R.Z. Valiev, T.G. Langdon, Prog. Mater. Sci. 51, 881 (2006).

8. A.P. Zhilyaev, T.G. Langdon, Prog. Mater. Sci. 53, 893 (2008).

9. R.B. Figueiredo, P.R. Cetlin, T.G. Langdon, Mater. Sci. Eng. A 528, 8198 (2011).

10. R.B. Figueiredo, P.H.R. Pereira, M.T.P. Aguilar, P.R. Cetlin, T.G. Langdon, Acta Mater. 60, 3190 (2012).

11. A. Loucif, R.B. Figueiredo, M. Kawasaki, T. Baudin, F. Brisset, R. Chemam, T.G. Langdon, J. Mater. Sci. 47, 7815 (2012).

12. T.G. Langdon, Metal Sci. 16, 175 (1982).

13. M. Kawasaki, T.G. Langdon, Mater. Sci. Eng. A 528, 6140 (2011).

14. M. Kawasaki, S. Lee, T.G. Langdon, Scripta Mater. 61, 963 (2009).

15. M. Kawasaki, A.de.A. Mendes, V.L. Sordi, M. Ferrante, T.G. Langdon, J. Mater. Sci. 46, 155 (2011).

16. T.G. Langdon, Acta Metall. Mater. 42, 2437 (1994).

17. R.Z. Valiev, T.G. Langdon, Acta Metall. Mater. 41, 949 (1993).

18. R.B. Figueiredo, T.G. Langdon, J. Mater. Sci. 43, 7366 (2008).

19. M. Kawasaki, N. Balasubramanian, T.G. Langdon, Mater. Sci. Eng. A528, 6624 (2011). 